\title{
Persistence in the performance of South African unit trusts
}

\author{
J.F.C. von Wielligh \& E. vd M. Smit \\ Graduate School of Business, University of Stellenbosch, P.O. Box 610, Bellville, 7535 South Africa
}

Received May 2000

\begin{abstract}
The persistence of performance of the General Equity Unit Trusts and All Unit Trusts that traded in South Africa during the period January 1988 to December 1997 and January 1993 to December 1997, is analysed using three models of performance measurement, namely the Capital Asset Pricing Model, a two-factor Arbitrage Pricing Theory model and a three-factor Arbitrage Pricing Theory (APT) model developed in this study. The Capital Asset Pricing Model does not explain the relative returns of the different portfolios. Both APT models account for almost all of the cross-sectional variation in expected returns. It is shown that there is evidence of both short-term and long-term persistence in performance of South African unit trusts. It appears that the worst performing unit trust portfolio tends to stay the worst performer. The portfolio of unit trusts with an average monthly return may eventually become the top performing portfolio, while the top performer over time tends to becomes an average performing portfolio.
\end{abstract}

\section{Introduction}

The aim of this study is to determine whether evidence of persistence in performance exists amongst South African unit trusts. From the literature review in the second section it is clear that the periods of analyses and the yardstick used to determine performance, have an influence on all conclusions. Four data sets are discussed in the third section which allow analyses over a five-year and a ten-year period as well as for both General Equity Unit Trusts and All Unit Trusts.

The fourth section deals with the three models of performance measurement which are employed in the analyses to ensure more than one yardstick. These are the Capital Asset Pricing Model (CAPM), a two-factor Arbitrage Pricing Theory (APT) model and a three-factor APT model.

Short-term persistence of performance as well as long-term persistence of performance of unit trusts are studied in the fifth section. The performance of past-winners is also examined. The study is concluded with a summary of the central findings.

\section{Literature review}

Over the years different researchers have derived different conclusions about the persistence of performance of unit trusts and specifically South African unit trusts. Knight \& Firer (1989) present evidence that over the period 1977 to 1986, trusts have performed either consistently well or consistently poorly. Smith \& Chapman (1994), Biger \& Page (1994) and Oldfield \& Page (1997), amongst others, conclude that there is little evidence of market timing ability amongst portfolio managers of South African unit trusts. They could not find any evidence of skills in selecting and switching securities within each asset class. Gavin concurs:

'Fund managers were not able to consistently outperform the market, neither did any manager consistently perform worse than the market. There is very little "persistence" in performance amongst fund managers. In other words, if a fund manager performed well in one period it does not imply that he will perform well in the subsequent period' (1995: 104).
On the other hand Theron (1996) and De Lange (1996) argue that there is some evidence of persistence of performance of unit trusts in South Africa. They advise that it is important to invest in one of the better performers, which in the long run can make a significant difference in returns. If invested in the top quartile of best performers, one will consistently obtain positive returns. However, according to the Unit Trust Handbook (1997) only one in five of the funds in the top quartile of a five-year league table are likely to remain in the top quartile over the next five years.

Meyer (1997) examines the persistence of South African unit trusts using the Jensen measure together with the security market line and the All Share Index over four-year, two-year and one-year intervals. Meyer (1997) concludes that the results are comparable to those obtained in much bigger markets and that some persistence in performance of unit trusts in the South African environment does exist. The repeat winner phenomenon exists over two-year periods for total returns and the repeat loser phenomenon is present over one-year, two-year and four-year time periods at a much higher frequency. Meyer concludes that:

'Persistence in performance seems to exist and it appears to be a guide to beat the pack in the long run.

The longer the evaluation period, the better the results'

(1997: 11).

Most research done on mutual funds in the USA point towards positive persistence in performance. Grinblatt \& Titman (1992), Hendricks, Patel \& Zeckhauser (1993), Goetzmann \& Ibbotson (1994), Brown \& Goetzmann (1995), Elton, Gruber \& Blake (1996) and Carhart (1997) all agree that there is some evidence of persistence in mutual fund performance.

The conclusions reached in any one study, however, are model and benchmark dependent (see Page, 1993). Therefore, in order to add to the robustness of the current state of knowledge about persistence in performance in the South African market, due to the fact that most research is CAPM based, the APT framework is utilised in the current study. 
The Capital Asset Pricing Model (CAPM) is the equation of the security market line showing the relationship between the expected return and beta. Arbitrage Pricing Theory (APT) is based on fewer and less restrictive assumptions than the CAPM and is also a more general model allowing for more than one risk factor to underlie share returns. The APT is based on the assumptions that markets are perfectly competitive and frictionless and that investors prefer more wealth to less wealth and are risk averse.

Individuals share the belief that for the set of assets being considered, the time series process underlying the generation of security returns can be represented by the following linear k-factor model:

$$
R_{n}=E\left(R_{i t}\right)+\sum_{k=1}^{K} B_{i k} f_{k t}+\varepsilon_{i t}
$$

where:

$R_{i t}=$ realised returns earned by asset $\mathrm{i}$ in time period $\mathrm{t}$, where $i=1,2 \ldots n$ and $t=1,2 \ldots T$;

$E\left(R_{i t}\right)=$ the expected rate of return of asset $i$ for period $t$ at the beginning of period $t$;

$b_{i k}=a$ coefficient that measures the sensitivity of $R_{t 1}$ to movements in $\mathrm{f}_{\mathrm{kt}}$;

$f_{k t}=$ the $k_{t h}$ risk factor that impacts on asset i's return, where $k=1,2 \ldots K$. All risk factors represent unexpected movements in pervasive economic forces and have an expected value of zero; and

$\varepsilon_{\mathrm{il}}=$ a normally distributed random error $\mathrm{t}$ which measures the unexplained residual return of asset $i$ in period $\mathrm{t}$.

Page (1985) concludes that in comparing the APT and the CAPM, the APT was found to be substantially better with regard to the explanation of variability in South African share returns and that the underlying macroeconomic variables determining the return generation process can be divided into those that primarily influence the mining sector and those that affect the industrial sector to a greater extent.

According to Ross (1976) arbitrage theory requires essentially identical expectations and agreement on the beta coefficients if the identification of ex ante beliefs with ex post realisations is to provide empirically fruitful results. Page (1989) and Barr (1989) both conclude that a two-factor model is the best benchmark to use in measuring security price performance in South Africa. Davidson (1993) concurs that the CAPM is not an appropriate model to use on the JSE, but at the same time argues that the APT is far from operational.

Reese (1993) confirms that in terms of the JSE as a whole, two or three factors appear to be priced, although the research on a yardstick for unit trusts' performance by Biger \& Page (1993) points towards an appropriate model containing three to five factors.

Van Rensburg \& Slaney (1997) argue that a two index 'multi-market model' when employing the JSE All Gold and Industrial Indices as explanatory variables, aids the economic interpretation of the results as well as introducing considerable efficiency in the ensuing cross-sectional estimation procedures. It also provides a model that is more easily applied by practitioners and bypasses the well-documented difficulties associated with factor analysis. They conclude that the different sources of risk are rewarded with risk premia of different magnitudes and that the large majority of JSE shares are influenced by either the Mining or Industrial Indices but seldom by both to an equal degree. The two-factor APT model has pricing implications not compatible with the CAPM employing the JSE All Share Index as the market proxy.

Van Rensburg (1998) studies the effect of economic forces on the JSE and concludes that the ritual 'poorly specified market portfolio' appeal will always be the last untestable defense of the CAPM. However, his results indicate that the CAPM, as conventionally specified by South African academics and practitioners (i.e. using the JSE All Share Index as a market proxy), is seriously flawed. The relative superiority of the Slaney (1995) two-index APT model is demonstrated by using the Industrial and All Gold Indices as observable proxies. It is argued that not only does this procedure significantly improve the explanatory power of models using pre-specified macroeconomic variables, but also that its omission leads to upward bias in the variances of the coefficient estimators of these models.

\section{Data and sample selection}

Four samples of data are used, namely all ten General Equity Unit Trusts that traded in South Africa over the period January 1988 to December 1997 (first sample), the General Equity Unit Trusts that traded in South Africa over the period January 1993 to December 1997 (second sample) and all Unit Trusts that traded in South Africa during these periods are used in the third and fourth samples (21 and 42 ) respectively. Trusts that were in existence over the entire five- and ten-year periods are included in the four samples respectively.

Monthly data was used. Selling prices were obtained from the Money Mate databank. Monthly rates of returns were calculated using the following equation:

$$
R_{i t}=\frac{P_{i t}-P_{i t-1}}{P_{i t-1}}
$$

where:

$\mathbf{R}_{\mathbf{t}}=$ the monthly rate of return of unit trust $\mathrm{i}$ in period $t$;

$P_{n}=$ the monthly selling price of unit trust $i$ in period $t$; and $P_{t-1}=$ the monthly selling price of unit trust $i$ in period $t-1$.

The yield on the three-month Treasury Bill is used to represent the risk-free rate of retum. The data is obtained from INet for the period January 1988 to December 1997 on a monthly basis as a yearly rate of return. The monthly risk free rate of return over the ten-year period was recalculated on a monthly basis. The monthly excess rate of return for the four samples were calculated by subtracting the risk free rate from the monthly rate of return as determined by equation 2 .

Three models of performance measurement were employed: the Capital Asset Pricing Model as described in Ross, Westerfield \& Jordan (1993), a two-factor Arbitrage Pricing Theory model (Van Rensburg \& Slaney, 1997) and a threefactor Arbitrage Pricing Theory model developed in this study and suggested by Van Rensburg. 


\section{Capital Asset Pricing Model (CAPM)}

The first model of performance measurement is the CAPM, specified as

$$
\text { PORTF }_{i t}=\alpha_{i T}+\beta_{i T} \text { ASHARE }_{t}+\varepsilon_{i t} t=1,2 \ldots T \ldots
$$

where:

$$
\begin{aligned}
\text { PORTF }_{\mathrm{it}}= & \text { the average monthly excess } 1 \text { return for portfolio } \\
& \mathrm{i} \text { in period } \mathrm{t} ; \\
\text { ASHARE }_{\mathrm{t}}= & \text { the monthly rate of return of the All Share } \\
& \text { Index }{ }^{2} \text { in period } \mathrm{t} \text {; and } \\
\varepsilon_{\mathrm{it}} & \text { the stochastic error term of unit trust } \mathrm{i} \text { in period }
\end{aligned}
$$

\section{Two-factor model}

The two-factor APT model has the following specification:

PORTF $_{i t}=\alpha_{i T}+\beta_{i T}$ AGOLD $_{t}+c_{I T}$ INDUST $_{t}+\varepsilon_{i t} t=1,2 \ldots T$

where:

$A_{G O L D}=$ the monthly rate of return of the All Gold Index in period $t$; and

$\mathrm{INDUST}_{\mathbf{l}}=$ the monthly rate of return of the Industrial Index in period $t$.

Data on a monthly basis for the ten-year period is obtained for the All Share Index, the All Gold Index and the Industrial Index, from I-Net. The monthly returns are calculated using the same method as for the portfolios.

This model is based on the findings of Van Rensburg \& Slaney who claim that

'The empirical findings strongly suggest that a two index model, employing the JSE Industrial and All Gold Indices as "prescribed factors", is a more appropriate approach to adopt in asset pricing applications such as portfolio performance evaluation and calculating South African companies' cost of equity capital' (1997: 20).

\section{Three-factor model}

This model contains an additional factor intended to price risk explicity:

PORTF $_{i t}=\alpha_{i T}+\beta_{i T}$ AGOLD $_{t}+c_{i T}$ INDUST $_{t}+d_{i T}$ STDEV $_{i t}+\varepsilon_{i t} \quad(5)$ $t=1,2 \ldots T$

where:

STDEV $_{\mathrm{it}}=$ the standard deviation of the monthly rate of return of portfolio $i$ in period $t$.

Summary statistics for the factor portfolios reported in Table 1 indicate that the two-factor model can explain considerable variation in returns for both the five- and ten-year periods. First, note the relative high variance of the AGOLD and the INDUST and their low correlations with each other. This suggests that the two-factor model can explain sizeable time-series variation. Second, the low cross-correlations imply that multicollinearity does not substantially affect the estimated two-factor model loadings.

\section{Empirical results}

Persistence in the current year return sorted unit trust portfolios (base case)

For all four data samples (All Unit Trusts and General Equity Unit Trusts over ten- and five-year periods), three equally weighted portfolios of unit trusts have been formed based on the current year's excess return using a modified version of the methodology of Hendricks, Patel \& Zeckhauser (1993). On the first of January of each year, three equally weighted portfolios of unit trusts, using reported yearly returns for the current year, are formed. The top performers are included in portfolio 1 (PORTF1), the average performers in portfolio 2 (PORTF2) and the worst performers in portfolio 3 (PORTF3).

The portfolios are held for one year after which they are reformed. From this, time series of monthly excess returns of

\begin{tabular}{|c|c|c|c|c|c|}
\hline \multicolumn{6}{|c|}{$\begin{array}{c}\text { FIVE-YEAR PERIOD } \\
\text { (January } 1993-\text { December 1997) }\end{array}$} \\
\hline \multirow[t]{2}{*}{ Factor portfolio } & \multirow{2}{*}{$\begin{array}{l}\text { Average monthly } \\
\text { return }\end{array}$} & \multirow{2}{*}{$\begin{array}{l}\text { Standard } \\
\text { deviation }\end{array}$} & \multicolumn{3}{|c|}{ Cross-correlations } \\
\hline & & & ASHARE & AGOLD & INDUST \\
\hline ASHARE & $1.177 \%$ & $4.504 \%$ & 1.000 & & \\
\hline AGOLD & $0.641 \%$ & $11.363 \%$ & 0.600 & 1.000 & \\
\hline INDUST & $0.979 \%$ & $4.303 \%$ & 0.850 & 0.198 & 1.000 \\
\hline \multirow{2}{*}{\multicolumn{6}{|c|}{$\begin{array}{c}\text { TEN-YEAR PERIOD } \\
\text { (January } 1988 \text { - December 1997) }\end{array}$}} \\
\hline & & & & & \\
\hline \multirow[t]{2}{*}{ Factor portfolio } & Average monthly & Standard & \multicolumn{3}{|c|}{ Cross-correlations } \\
\hline & & & ASHARE & AGOLD & INDUST \\
\hline ASHARE & $1.173 \%$ & $4.840 \%$ & 1.000 & & \\
\hline AGOLD & $0.621 \%$ & $10.140 \%$ & 0.588 & 1.000 & \\
\hline INDUST & $1.350 \%$ & $4.670 \%$ & 0.857 & 0.217 & 1.000 \\
\hline
\end{tabular}
each of the three portfolios are obtained from January 1989 to December 1997 for the two ten-year samples (All Unit Trusts and General Equity Unit Trusts) and January 1993 to December 1997 for the two five-year samples (All Unit Trusts and General Equity Unit Trusts).

Table 1 Performance measurement model summary statistics 
Multiple regression analyses are performed with the three portfolios' returns as the dependant variables. For each of the four samples three multiple regression analyses are run pertaining to each of the three models of performance measurement. A total of 36 multiple regression analyses are reported on in Tables 2 and 3. The portfolios of both All Unit Trusts and General Equity Unit Trusts demonstrate strong variation in mean returns, as shown in these tables.

The mean monthly excess returns of the three portfolios decline with portfolio rank for all four samples. Because the portfolios are formed on the basis of the current year's performance this pattern is expected. The dispersions of the four samples indicate sizeable annualized spreads in returns of approximately $9 \%$ in the case of the General Equity Unit Trusts and $30 \%$ in the case of All Unit Trusts. Cross-sectional variation in return is considerably larger among the portfolios of All Unit Trusts than General Equity Unit Trusts and also larger among the portfolios in the ten-year samples than the five-year samples in three of the four samples. In all four samples the top portfolio (PORTFl) exhibits positive excess returns, while the worst performers (PORTF3) show negative returns.
In the case of the General Equity Unit Trust portfolios, the CAPM betas for the three portfolios are almost identical and they consistently decrease from PORTF 1 to PORTF3, except for the five-year period. For the All Share Unit Trust portfolios, the CAPM betas consistently decrease from PORTF 1 to PORTF3 indicating a higher risk for the portfolios with the higher excess returns. In all the samples the average portfolio (PORTF2) shows the best correlation with the All Share Index (ASHARE). During the five-year period, the General Equity Unit Trust portfolios correlate better with ASHARE than the All Share Unit Trust portfolios, while during the ten-year period the opposite is true.

The results of two-factor model indicates that the General Equity Unit Trust portfolios are less sensitive to the All Gold Index (AGOLD) than the All Share Unit Trust portfolios. The opposite is true for the Industrial Index (INDUST). Note the small regression coefficients for the PORTF3's of the All Unit Trust portfolios. High adjusted R-square values indicate a good fit between the performance of the portfolios and the two-factor model, especially in the case of the high and medium return portfolios.

The three-factor model does not do substantially better than the two-factor model in terms of the adjusted R-square values

Table 2 Portfolios of general equity unit trusts formed on the current year returns

\begin{tabular}{|c|c|c|c|c|c|c|c|}
\hline \multirow{3}{*}{\multicolumn{2}{|c|}{ Portfolio }} & \multicolumn{3}{|c|}{ FIVE-YEAR PERIOD } & \multicolumn{3}{|c|}{ TEN-YEAR PERIOD } \\
\hline & & PORTFI & PORTF2 & PORTF3 & PORTF1 & PORTF2 & PORTF3 \\
\hline & & (High) & (Med) & (Low) & (High) & (Med) & (Low) \\
\hline \multicolumn{2}{|c|}{ Mean monthly excess return } & $0.723 \%$ & $0.069 \%$ & $-0.004 \%$ & $0.564 \%$ & $0.061 \%$ & $-0.269 \%$ \\
\hline \multicolumn{2}{|c|}{ Std deviation } & $3.480 \%$ & $3.493 \%$ & $3.384 \%$ & $3.898 \%$ & $3.807 \%$ & $4.681 \%$ \\
\hline \multirow{6}{*}{ CAPM } & Alpha & $-0.122 \%$ & $-0.799 \%$ & $-1.205 \%$ & $-0.317 \%$ & $-0.801 \%$ & $-1.113 \%$ \\
\hline & t-Stat & -0.697 & -5.498 & -6.796 & -2.271 & -5.944 & -3.579 \\
\hline & ASHARE & 0.717 & 0.738 & 0.692 & 0.751 & 0.735 & 0.719 \\
\hline & t-Stat & 19.015 & 23.445 & 18.033 & 26.671 & 27.045 & 11.472 \\
\hline & Adj R-sq & 0.859 & 0.903 & 0.846 & 0.869 & 0.872 & 0.550 \\
\hline & DW-Stat & 2.160 & 2.211 & 2.347 & 2.197 & 2.475 & 2.979 \\
\hline \multirow{8}{*}{$\begin{array}{l}\text { 2-Factor } \\
\text { Model }\end{array}$} & Alpha & $0.028 \%$ & $-0.658 \%$ & $-1.082 \%$ & $-0.369 \%$ & $-0.873 \%$ & $-1.108 \%$ \\
\hline & t-Stat & 0.133 & -3.996 & -5.792 & -2.153 & -6.088 & -3.314 \\
\hline & AGOLD & 0.072 & 0.080 & 0.065 & 0.088 & 0.092 & 0.114 \\
\hline & t-Stat & 3.884 & 5.497 & 3.922 & 5.305 & 6.621 & 3.499 \\
\hline & INDUST & 0.663 & 0.690 & 0.664 & 0.687 & 0.687 & 0.616 \\
\hline & t-Stat & 13.612 & 17.984 & 15.249 & 18.981 & 22.693 & 8.721 \\
\hline & Adj R-sq & 0.795 & 0.873 & 0.826 & 0.808 & 0.859 & 0.494 \\
\hline & DW-Stat & 2.111 & 2.118 & 2.412 & 2.562 & 2.300 & 2.901 \\
\hline \multirow{10}{*}{$\begin{array}{l}\text { 3-Factor } \\
\text { Model }\end{array}$} & Alpha & $-1.380 \%$ & $0.228 \%$ & $-0.765 \%$ & $-0.800 \%$ & $-0.327 \%$ & $-1.630 \%$ \\
\hline & t-Stat & -2.799 & 0.466 & -1.767 & -2.329 & -1.015 & -5.073 \\
\hline & AGOLD & 0.073 & 0.077 & 0.067 & 0.083 & 0.093 & 0.107 \\
\hline & t-Stat & 4.261 & 5.354 & 3.993 & 4.882 & 6.752 & 3.611 \\
\hline & INDUST & 0.656 & 0.703 & 0.664 & 0.678 & 0.698 & 0.626 \\
\hline & I-Stat & 14.454 & 18.453 & 15.201 & 18.609 & 22.932 & 9.785 \\
\hline & STDEV & 1.006 & 0.793 & -0.258 & 0.365 & 0.545 & 0.304 \\
\hline & I-Stat & 3.107 & -1.919 & -0.810 & 1.446 & -1.886 & 4.874 \\
\hline & Adj R-sq & 0.822 & 0.979 & 0.825 & 0.810 & 0.862 & 0.584 \\
\hline & DW-Stat & 2.279 & 2.051 & 2.408 & 2.632 & 2.296 & 2.814 \\
\hline
\end{tabular}


Table 3 Portfolios of All Unit Trusts formed on the current year returns

\begin{tabular}{|c|c|c|c|c|c|c|c|}
\hline & & \multicolumn{3}{|c|}{ FIVE-YEAR PERIOD } & \multicolumn{3}{|c|}{ TEN-YEAR PERIOD } \\
\hline \multirow{2}{*}{\multicolumn{2}{|c|}{ Portfolio }} & PORTF1 & PORTF2 & PORTF3 & PORTF1 & PORTF2 & PORTF3 \\
\hline & & (High) & (Med) & (Low) & (High) & (Med) & (Low) \\
\hline \multicolumn{2}{|c|}{ Mean monthly excess return } & $1.039 \%$ & $0.035 \%$ & $-1.740 \%$ & $0.782 \%$ & $-0.007 \%$ & $-1.430 \%$ \\
\hline \multicolumn{2}{|c|}{ Std deviation } & $4.000 \%$ & $3.337 \%$ & $3.608 \%$ & $4.314 \%$ & $3.727 \%$ & $4.077 \%$ \\
\hline & Alpha & $0.069 \%$ & $-0.791 \%$ & $-2.344 \%$ & $-0.163 \%$ & $-0.857 \%$ & $-2.200 \%$ \\
\hline & t-Stat & 0.344 & -5.481 & -6.290 & -0.893 & -6.815 & -8.657 \\
\hline \multirow[t]{7}{*}{ CAPM } & ASHARE & 0.823 & 0.702 & 0.514 & 0.806 & 0.724 & 0.656 \\
\hline & t-Stat & 18.857 & 22.464 & 6.368 & 21.833 & 28.582 & 12.810 \\
\hline & Adj R-sq & 0.857 & 0.895 & 0.401 & 0.816 & 0.884 & 0.604 \\
\hline & DW-Stat & 1.684 & 2.185 & 1.632 & 1.707 & 2.608 & 2.374 \\
\hline & Alpha & $0.369 \%$ & $-0.663 \%$ & $-2.160 \%$ & $-0.033 \%$ & $-0.883 \%$ & $-2.037 \%$ \\
\hline & $t-S t a t$ & 1.450 & -4.412 & -6.048 & -0.149 & -5.971 & -7.800 \\
\hline & AGOLD & 0.188 & 0.077 & 0.153 & 0.193 & 0.111 & 0.196 \\
\hline \multirow{9}{*}{$\begin{array}{l}\text { 2-Factor } \\
\text { Model }\end{array}$} & t-Stat & 8.384 & 5.839 & 4.844 & 9.031 & 7.689 & 7.724 \\
\hline & INDUST & 0.561 & 0.662 & 0.329 & 0.594 & 0.644 & 0.441 \\
\hline & t-Stat & 9.454 & 18.900 & 3.958 & 12.802 & 20.607 & 7.987 \\
\hline & Adj R-sq & 0.769 & 0.884 & 0.442 & 0.742 & 0.844 & 0.593 \\
\hline & DW-Stat & 1.831 & 2.220 & 1.698 & 1.893 & 2.364 & 2.410 \\
\hline & Alpha & $-0.474 \%$ & $-0.112 \%$ & $-0.833 \%$ & $-1.205 \%$ & $-0.425 \%$ & $-2.462 \%$ \\
\hline & t-Stat & -0.964 & -0.223 & -2.749 & -2.599 & -1.251 & -7.481 \\
\hline & AGOLD & 0.173 & 0.073 & 0.106 & 0.172 & 0.106 & 0.199 \\
\hline & t-Stat & 7.423 & 5.207 & 4.633 & 7.802 & 7.280 & 7.941 \\
\hline \multirow{6}{*}{$\begin{array}{l}\text { 3-Factor } \\
\text { Model }\end{array}$} & INDUST & 0.559 & 0.661 & 0.440 & 0.587 & 0.641 & 0.438 \\
\hline & t-Stat & 9.673 & 18.912 & 7.336 & 13.032 & 20.618 & 8.064 \\
\hline & STDEV & 0.351 & -0.380 & -0.352 & 0.586 & -0.292 & 0.167 \\
\hline & t-Stat & 1.985 & -1.151 & -7.764 & 2.846 & -1.496 & 2.068 \\
\hline & Adj R-sq & 0.781 & 0.885 & 0.726 & 0.759 & 0.846 & 0.605 \\
\hline & DW-Stat & 1.796 & 2.184 & 2.308 & 2.022 & 2.351 & 2.394 \\
\hline
\end{tabular}

which the STDEV variable is frequently insignificant and unstable in terms of its sign.

\section{Persistence in one-year return-sorted unit trust port- folios}

The purpose of this section is to determine whether shortterm persistence exists in the performance of South African unit trusts. Once again for all four data samples (All Unit Trusts and General Equity Unit Trusts over ten- and five-year periods), three equally weighted portfolios of unit trusts have been formed. For these analyses the portfolios have been formed on the basis of lagged one-year returns, thus replicating the methodology of Hendricks et al. (1993). On the first of January of each year, three equal weighted portfolios of unit trusts are formed, using reported yearly returns of the previous year. The top performers are included in portfolio 1 (PORTF 1), the average performers in portfolio 2 (PORTF2) and the worst performers in portfolio 3 (PORTF3).

The portfolios are held for one year after which they are reformed. Once again a total of 36 multiple regression analyses have been run using the three models of performance measurement. Summaries of the results of the multiple regression analyses pertaining to the General Equity Unit Trusts and All Unit Trusts are shown in Tables 4 and 5 respectively.

Once again variations in mean returns between the portfolios are demonstrated, although not as pronounced as in the base case. In the case of General Equity Unit Trusts, PORTF1 shows the highest monthly excess returns and PORTF2 the lowest. In the case of All Unit Trusts, the monthly excess returns of the three portfolios increase with portfolio rank order. PORTF1 has the lowest (negative) monthly excess returns of all portfolios. The four samples indicate annualised spreads of approximately $3 \%$ for the General Equity Unit Trusts and between two and $14 \%$ for All Unit Trusts. Cross-sectional variation in returns is considerably larger among the portfolios of All Unit Trusts than General Equity Unit Trusts and also larger amongst the portfolios in the ten-year samples than the five-year samples.

The CAPM does not explain the relative returns of these portfolios. There is no consistent relation between the CAPM betas and the returns on the three portfolios. The CAPM betas should be higher for higher returns indicating a higher risk for the portfolios with the higher excess returns. In all the samples the average portfolio (PORTF2) shows the best correlation with the All Share Index (ASHARE), while during the 
Table 4 Portfolios of General Equity Unit Trusts formed on lagged one-year returns

\begin{tabular}{|c|c|c|c|c|c|c|c|}
\hline \multirow{2}{*}{ Portfolio } & & \multicolumn{3}{|c|}{ FIVE-YEAR PERIOD } & \multicolumn{3}{|c|}{ TEN-YEAR PERIOD } \\
\hline & & PORTF I & PORTF2 & PORTF3 & PORTFI & PORTF2 & PORTF3 \\
\hline & & (High) & (Med) & (Low) & (High) & (Med) & (Low) \\
\hline \multicolumn{2}{|c|}{ Mean monthly excess return } & $0.310 \%$ & $0.000 \%$ & $0.246 \%$ & $0.217 \%$ & $0.057 \%$ & $0.083 \%$ \\
\hline \multicolumn{2}{|c|}{ Std deviation } & $3.291 \%$ & $3.540 \%$ & $3.676 \%$ & $4.601 \%$ & $3.864 \%$ & $3.907 \%$ \\
\hline \multirow{6}{*}{ CAPM } & Alpha & $-0.463 \%$ & $-0.883 \%$ & $-0.765 \%$ & $-0.602 \%$ & $-0.826 \%$ & $-0.769 \%$ \\
\hline & I-Stat & -2.392 & -6.225 & -5.175 & -1.939 & -6.407 & -5.523 \\
\hline & ASHARE & 0.657 & 0.751 & 0.737 & 0.698 & 0.752 & 0.749 \\
\hline & t-Stat & 15.675 & 24.431 & 23.040 & 11.158 & 28.945 & 26.792 \\
\hline & Adj R-sq & 0.806 & 0.910 & 0.900 & 0.536 & 0.887 & 0.861 \\
\hline & DW-Stat & 2.085 & 2.339 & 2.154 & 2.860 & 2.420 & 1.965 \\
\hline \multirow{8}{*}{$\begin{array}{l}\text { 2-Factor } \\
\text { Model }\end{array}$} & Alpha & $-0.353 \%$ & $-0.732 \%$ & $-0.615 \%$ & $-0.633 \%$ & $-0.871 \%$ & $-0.846 \%$ \\
\hline & t-Stat & -1.761 & -4.311 & -3.431 & -1.925 & -5.693 & -5.011 \\
\hline & AGOLD & 0.049 & 0.087 & 0.080 & 0.093 & 0.102 & 0.096 \\
\hline & t-Stat & 2.751 & 5.778 & 5.045 & 2.915 & 6.839 & 5.866 \\
\hline & INDUST & 0.645 & 0.691 & 0.681 & 0.626 & 0.682 & 0.683 \\
\hline & t-Stat & 13.820 & 17.453 & 16.292 & 9.006 & 21.111 & 19.172 \\
\hline & Adj R-sq & 0.789 & 0.869 & 0.850 & 0.493 & 0.844 & 0.815 \\
\hline & DW-Stat & 2.076 & 2.242 & 2.169 & 2.795 & 2.315 & 2.378 \\
\hline \multirow{10}{*}{$\begin{array}{l}\text { 3-Factor } \\
\text { Model }\end{array}$} & Alpha & $-0.988 \%$ & $-0.601 \%$ & $-0.472 \%$ & $-1.194 \%$ & $-0.330 \%$ & $-0.976 \%$ \\
\hline & $\mathrm{t}$-Stat & -2.216 & -1.307 & -0.975 & -3.744 & -0.853 & -3.352 \\
\hline & AGOLD & 0.047 & 0.087 & 0.079 & 0.087 & 0.103 & 0.096 \\
\hline & t-Stat & 2.700 & 5.732 & 4.941 & 3.008 & 6.952 & 5.816 \\
\hline & INDUST & 0.649 & 0.693 & 0.679 & 0.634 & 0.684 & 0.684 \\
\hline & t-Stat & 14.072 & 17.025 & 16.011 & 10.078 & 21.286 & 19.115 \\
\hline & STDEV & 0.484 & -0.110 & -0.104 & 0.369 & -0.468 & 0.119 \\
\hline & t-Stat & 1.590 & -0.307 & -0.318 & 4.914 & -1.521 & 0.552 \\
\hline & Adj R-sq & 0.794 & 0.867 & 0.848 & 0.584 & 0.846 & 0.819 \\
\hline & DW-Stat & 2.092 & 2.242 & 2.136 & 2.713 & 2.295 & 2.378 \\
\hline
\end{tabular}

five-year period, the General Equity Unit Trust portfolios correlate better with the All Share Index (ASHARE) than the All Share Unit Trust portfolios. During the ten-year period, the opposite holds.

In Tables 4 and 5 the same phenomena are observed as in the base case. Using the two-factor model, it follows that the General Equity Unit Trust portfolios are less sensitive to the All Gold Index (AGOLD) than the All Share Unit Trust portfolios, while the opposite holds for the Industrial Index (INDUST). High adjusted R-square values indicate a good correlation between the performance of the portfolios and the two-factor model in most cases. In all four samples the PORTF2's have the highest adjusted R-square values, which implies that the performance of the average portfolios can best be described by this model.

The three-factor model does not do substantially better than the two-factor model, as the values of the standard deviation of the portfolios (STDEV) are not significant in a number of cases.

In summary, the results show that short-term persistence does not exist for the All Share Unit Trust portfolios. In the case of the General Equity Unit Trust portfolios, however, there is evidence of persistence. The top portfolio (PORTFI) remains the portfolio with the highest average monthly excess return. PORTF2 and PORTF 3 change positions but still retain positive excess returns. Most of the persistence can be explained by common-factor sensitivities.

\section{Performance on past-winner unit trusts (1 year lag)}

To further investigate the persistence of past-winners, the following method is used - for the ten-year periods (both for the All Unit Trusts and General Equity Unit Trusts), three equally weighted portfolios have been formed in each year based on the previous year's yearly excess returns. The top performers are included in portfolio 1 (PORTF1), the average performers in portfolio 2 (PORTF2) and the worst performers in portfolio 3 (PORTF3).

The portfolios remain unchanged for the entire period and the average monthly excess returns are calculated for each portfolio for the formation year and in each of the next five years after formation. Figures 1 and 2 show the post-formation returns on the General Equity Unit Trust portfolios sorted on lagged one-year returns and the post-formation returns on 
Table 5 Portfolios of All Unit Trusts formed on lagged one-year returns

\begin{tabular}{|c|c|c|c|c|c|c|c|}
\hline & & \multicolumn{3}{|c|}{ FIVE-YEAR PERIOD } & \multicolumn{3}{|c|}{ TEN-YEAR PERIOD } \\
\hline \multirow{2}{*}{\multicolumn{2}{|c|}{ Portfolio }} & PORTF1 & PORTF2 & PORTF3 & PORTFI & PORTF2 & PORTF3 \\
\hline & & (High) & (Med) & (Low) & (High) & (Med) & (Low) \\
\hline \multicolumn{2}{|c|}{ Mean monthly excess return } & $-0.913 \%$ & $0.007 \%$ & $0.246 \%$ & $-0.330 \%$ & $-0.190 \%$ & $-0.135 \%$ \\
\hline \multicolumn{2}{|c|}{ Std deviation } & $3.857 \%$ & $3.373 \%$ & $3.676 \%$ & $4.405 \%$ & $3.706 \%$ & $4.085 \%$ \\
\hline & Alpha & $-1.623 \%$ & $-0.821 \%$ & $-0.614 \%$ & $-1.206 \%$ & $-1.030 \%$ & $-0.984 \%$ \\
\hline & t-Stat & -4.401 & -5.241 & -2.796 & -4.808 & -7.907 & -4.725 \\
\hline \multirow[t]{7}{*}{ CAPM } & ASHARE & 0.603 & 0.703 & 0.731 & 0.746 & 0.716 & 0.724 \\
\hline & t-Stat & 7.558 & 20.737 & 15.372 & 14.758 & 27.264 & 17.247 \\
\hline & Adj R-sq & 0.488 & 0.879 & 0.800 & 0.670 & 0.874 & 0.735 \\
\hline & DW-Stat & 1.626 & 1.916 & 1.360 & 2.163 & 2.451 & 1.475 \\
\hline & Alpha & $-1.426 \%$ & $-0.707 \%$ & $-0.313 \%$ & $-1.137 \%$ & $-1.056 \%$ & $-0.760 \%$ \\
\hline & t-Stat & -3.932 & -4.659 & -1.355 & -4.295 & -6.254 & -3.666 \\
\hline & AGOLD & 0.154 & 0.064 & 0.203 & 0.169 & 0.093 & 0.238 \\
\hline 2-Factor & t-Stat & 4.810 & 4.805 & 9.966 & 6.554 & 5.681 & 11.792 \\
\hline \multirow[t]{8}{*}{ Model } & INDUST & 0.423 & 0.686 & 0.438 & 0.590 & 0.637 & 0.452 \\
\hline & t-Stat & 5.010 & 19.416 & 8.145 & 10.544 & 17.857 & 10.329 \\
\hline & Adj R-sq & 0.496 & 0.885 & 0.776 & 0.641 & 0.798 & 0.744 \\
\hline & DW-Stat & 1.668 & 2.184 & 1.780 & 2.208 & 2.404 & 1.688 \\
\hline & Alpha & $-0.340 \%$ & $-0.624 \%$ & $-0.587 \%$ & $-1.520 \%$ & $-0.201 \%$ & $-0.462 \%$ \\
\hline & 1-Stat & -1.032 & -1.554 & -1.379 & -4.753 & -0.564 & -1.124 \\
\hline & AGOLD & 0.111 & 0.065 & 0.200 & 0.171 & 0.095 & 0.240 \\
\hline & t-Stat & 4.325 & 4.758 & 9.598 & 6.733 & 5.952 & 11.799 \\
\hline 3-Factor & INDUST & 0.533 & 0.689 & 0.438 & 0.588 & 0.666 & 0.453 \\
\hline \multirow[t]{5}{*}{ Model } & t-Stat & 7.880 & 18.249 & 8.123 & 10.667 & 18.338 & 10.326 \\
\hline & STDEV & -0.285 & -0.057 & 0.101 & 0.170 & -0.567 & -0.116 \\
\hline & t-Stat & -6.279 & -0.223 & 0.769 & 2.067 & -2.697 & -0.840 \\
\hline & Adj R-sq & 0.699 & 0.883 & 0.774 & 0.652 & 0.806 & 0.743 \\
\hline & DW-Stat & 1.859 & 2.188 & 1.824 & 2.145 & 2.354 & 1.660 \\
\hline
\end{tabular}

the All Unit Trust portfolios sorted on lagged one-year returns respectively.

From both figures it is clear that the relative higher returns of the top portfolios are short-lived. It can also be seen that

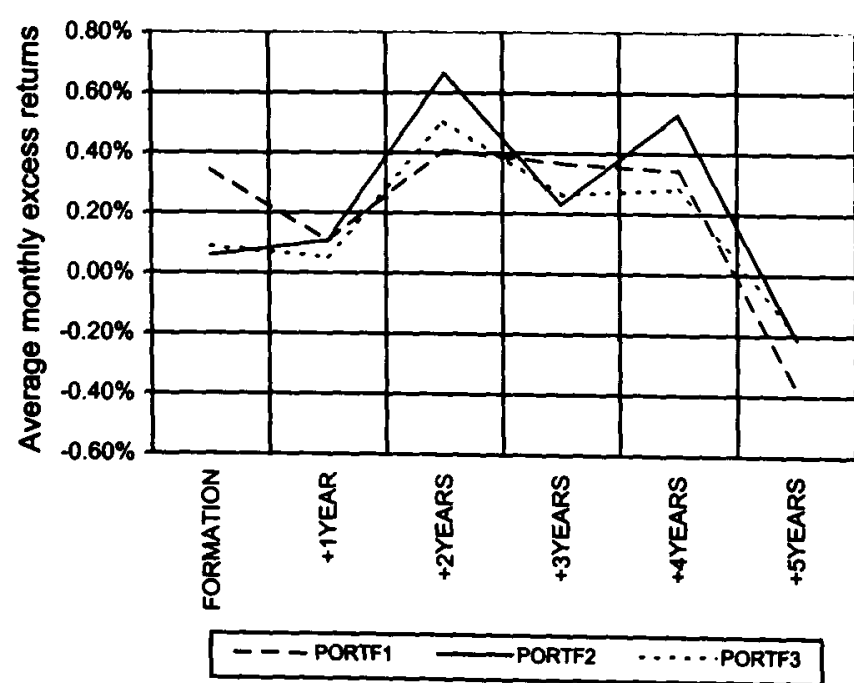

Figure 1 Post-formation returns on the General Equity Unit Trust portfolios sorted on lagged one-year returns the one-year performance persistence is mostly eliminated after one to two years. For both the General Equity Unit Trusts and the All Unit Trusts a trend of persistent under-performance of the worst portfolio (PORT3) is notable. It appears that

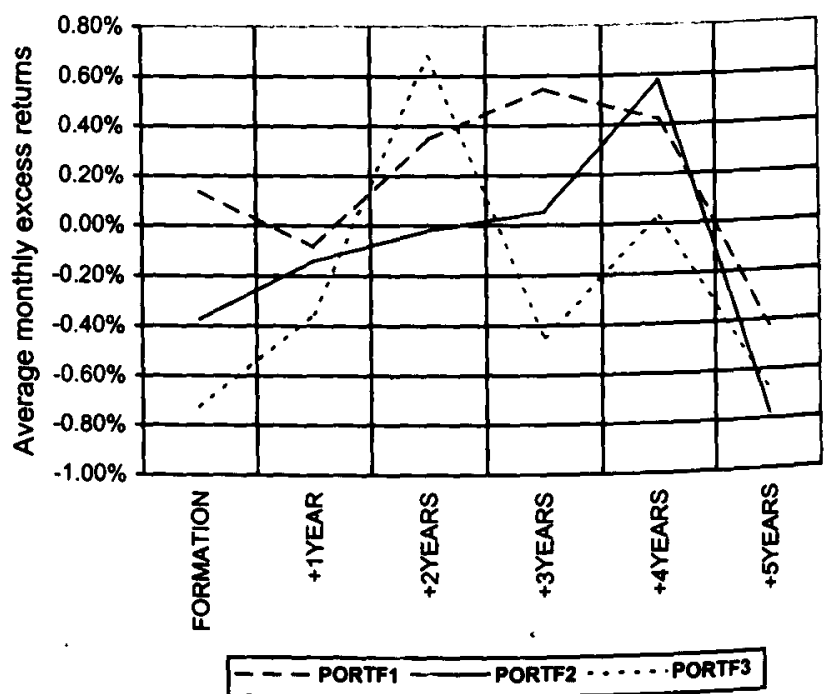

Figure 2 Post-formation returns on All Unit Trust portfolios sorted on lagged one-year returns 


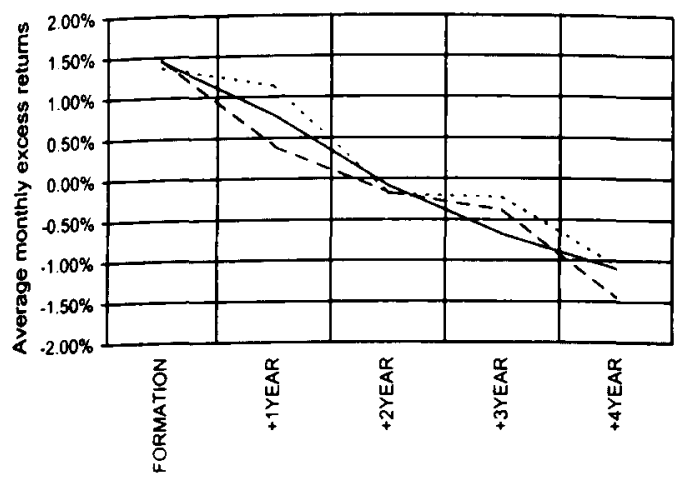

Figure 3 Post-formation returns on the General Equity Unit Trust portfolios sorted on lagged five-year returns

the average portfolio (PORTF2) in the case of General Equity Unit Trusts generates the best average monthly excess returns in most post-formation years.

Persistence in five-year return-sorted unit trust portfolios

To determine whether evidence can be found for longer term

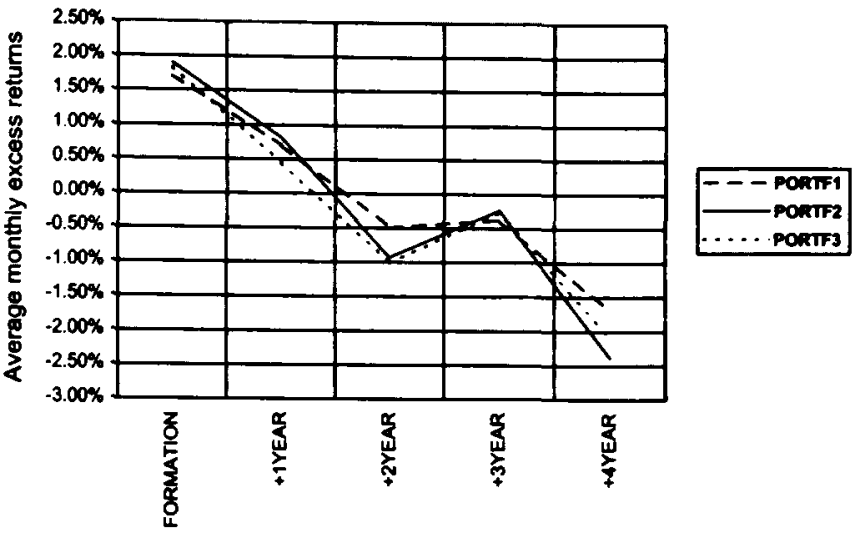

Figure 4 Post-formation returns on All Unit Trust portfolios sorted on lagged five-year returns

persistence in performance, portfolios of All Unit Trusts and General Equity Unit Trusts are formed on lagged five-year yearly returns. This is done for the ten-year data samples only.

Once again the methodology of Hendricks et al. (1993) is used. On the first of January of each year, three equally

Table 6 Portfolios of General Equity Unit Trusts and All Unit Trusts formed on lagged five-year returns over a ten-year period

\begin{tabular}{|c|c|c|c|c|c|c|c|}
\hline \multirow{3}{*}{\multicolumn{2}{|c|}{ Portfolio }} & \multicolumn{3}{|c|}{ GENERAL EQUITY UNIT TRUSTS } & \multicolumn{3}{|c|}{ ALL UNIT TRUSTS } \\
\hline & & PORTFI & PORTF2 & PORTF3 & PORTFI & PORTF2 & PORTF3 \\
\hline & & (High) & (Med) & (Low) & (High) & (Med) & (Low) \\
\hline \multicolumn{2}{|c|}{ Mean monthly excess return } & $0.032 \%$ & $0.185 \%$ & $-0.011 \%$ & $0.155 \%$ & $0.199 \%$ & $-0.766 \%$ \\
\hline \multicolumn{2}{|c|}{ Std deviation } & $3.510 \%$ & $3.425 \%$ & $3.609 \%$ & $3.531 \%$ & $3.525 \%$ & $4.265 \%$ \\
\hline \multirow{6}{*}{ CAPM } & Alpha & $-0.835 \%$ & $-0.661 \%$ & $-0.878 \%$ & $-0.722 \%$ & $-0.672 \%$ & $-1.661 \%$ \\
\hline & t-Stat & -5.398 & -4.369 & -4.584 & -4.853 & -4.372 & -4.870 \\
\hline & ASHARE & 0.737 & 0.718 & 0.736 & 0.745 & 0.740 & 0.762 \\
\hline & t-Stat & 21.990 & 21.946 & 17.762 & 23.135 & 22.238 & 10.309 \\
\hline & Adj R-sq & 0.891 & 0.891 & 0.842 & 0.901 & 0.893 & 0.641 \\
\hline & DW-Stat & 2.308 & 2.247 & 2.282 & 2.266 & 1.839 & $\cdot 1.844$ \\
\hline \multirow{8}{*}{$\begin{array}{l}\text { 2-Factor } \\
\text { Model }\end{array}$} & Alpha & $-0.683 \%$ & $-0.524 \%$ & $-0.732 \%$ & $-0.545 \%$ & $-0.435 \%$ & $-1.362 \%$ \\
\hline & t-Stat & -3.807 & -3.118 & -3.389 & -2.774 & -1.926 & -5.172 \\
\hline & AGOLD & 0.091 & 0.077 & 0.075 & 0.099 & 0.136 & 0.258 \\
\hline & I-Stat & 5.731 & 5.171 & 3.957 & 5.718 & 6.839 & 11.081 \\
\hline & INDUST & 0.670 & 0.674 & 0.686 & 0.650 & 0.558 & 0.441 \\
\hline & t-Stat & 16.036 & 17.195 & 13.642 & 14.188 & 10.609 & 7.183 \\
\hline & Adj R-sq & 0.851 & 0.863 & 0.796 & 0.823 & 0.767 & 0.783 \\
\hline & DW-Stat & 2.361 & 2.337 & 2.217 & 2.237 & 1.949 & 1.745 \\
\hline \multirow{10}{*}{$\begin{array}{l}\text { 3-Factor } \\
\text { Model }\end{array}$} & Alpha & $-0.632 \%$ & $-0.530 \%$ & $-0.578 \%$ & $-0.466 \%$ & $-1.261 \%$ & $-0.675 \%$ \\
\hline & t-Stat & -1.679 & -1.523 & -1.325 & -0.986 & -2.598 & -1.455 \\
\hline & AGOLD & 0.090 & 0.077 & 0.077 & 0.099 & 0.134 & 0.266 \\
\hline & t-Stat & 5.613 & 5.115 & 3.944 & 5.656 & 6.903 & 11.419 \\
\hline & INDUST & 0.670 & 0.674 & 0.687 & 0.651 & 0.560 & 0.457 \\
\hline & t-Stat & 15.898 & 16.466 & 13.547 & 13.938 & 10.898 & 7.500 \\
\hline & STDEV & -0.049 & 0.005 & -0.159 & -0.048 & 0.416 & -0.235 \\
\hline & t-Stat & -0.153 & 0.019 & -0.408 & -0.185 & 1.912 & -1.782 \\
\hline & Adj R-sq & 0.849 & 0.860 & 0.793 & 0.820 & 0.777 & 0.791 \\
\hline & DW-Stat & 2.356 & 2.338 & 2.166 & 2.236 & 2.021 & 1.705 \\
\hline
\end{tabular}


weighted portfolios of unit trusts are formed, using reported yearly returns of five years ago. The top performers are included in portfolio 1 (PORTF 1 ), the average performers in portfolio 2 (PORTF2) and the worst performers in portfolio 3 (PORTF3).

The portfolios are held unchanged for one year after which they are re-formed. A total of 18 multiple regression analyses are run using the three models of performance measurement. A summary of the results of the multiple regression analyses for the General Equity Unit Trusts and All Unit Trusts is shown in Table 6.

Using longer intervals of past returns does not reveal any more information regarding expected future returns. The variation in mean returns between the portfolios is very similar than in the case of the one-year lagged data. The annualised spreads are approximately $2 \%$ for the General Equity Unit Trusts and 12\% for All Unit Trusts. For both the General Equity Unit Trusts and the All Unit Trusts, PORTF2 has the highest monthly excess return, PORTF1 the average and PORTF3 has the lowest (and a negative) monthly excess return. Cross-sectional variation in returns is considerably larger amongst the worst performing portfolios (PORTF3).

The CAPM again does not explain the relative returns of these portfolios. However, the CAPM, the two-factor model and the three-factor model account for almost all of the crosssectional variation in expected return on portfolios sorted on lagged five-year returns in terms of adjusted R-squared values. As before the three-factor model does not significantly improve on the two-factor model.

In summary, the results show that long-term persistence does partially exist in the case of All Unit Trust portfolios and the General Equity Unit Trusts. The worst performing portfolio (PORTF3) remains the portfolio with the lowest (and negative) average monthly excess return. PORTF1 and PORTF2 change positions but retain positive excess returns. In both cases PORTF2 has the highest monthly excess return. Most of the persistence can be explained by common-factor sensitivities and almost all of the results from the analyses are statistically meaningful.

\section{Performance of past-winner unit trusts (five years lag)}

To determine the persistence of past-winners, the following method is used for the ten-year periods (both for the All Unit Trusts and General Equity Unit Trusts), three equally weighted portfolios have been formed in each year based on the yearly excess returns of five years ago. The top performers are included in portfolio 1 (PORTF1), the average performers in portfolio 2 (PORTF2) and the worst performers in portfolio 3 (PORTF3).

The formation of the portfolios remains unchanged for the entire period and the average monthly excess returns are calculated for each portfolio for the formation year and in each of the next five years after formation. Figures 3 and 4 show the post-formation returns on the General Equity Unit Trust portfolios sorted on lagged five-years returns and the postformation returns on the All Unit Trust portfolios sorted on lagged five-years returns respectively.

From both figures it can be seen that the spread of the average monthly excess returns of the portfolios is smaller than the spread of portfolios with post-formation returns sorted on lagged one-year. For the General Equity Unit Trusts the best performing portfolio in the formation year, almost always has the worst average monthly excess returns, while the worst performing portfolio in the formation year, shows the best results. PORTF2 remains the average performing portfolio for the entire period. Both graphs show a trend of decreasing av. erage monthly excess returns over time. The All Unit Trust portfolios have steeper slopes than the General Equity Unit Trust portfolios, starting with an average monthly excess return of approximately $1.7 \%$ decreasing to minus $2 \%$, comparing to the General Equity Trusts of $1.4 \%$ decreasing to minus $1 \%$.

\section{Conclusions}

In summary it can be said that there is clear evidence of persistence in performance amongst South African unit trusts. Considering only General Equity Unit Trusts, even more evidence of persistence exists. Although short-term persistence is present, there is even more evidence of long-term persistence. It appears as if the worst performing unit trusts tend to stay the bad performers over the long term, while the performance of the best and average performers converge to each other. Over the long term, the best performers may become the average performers, while the average performers may outperform the rest.

On the basis of this study, a long-term investor (five years) is advised to invest in a unit trust which has had an above average monthly excess return during the previous year, but is not the top category, and never to invest in the previous year's worst performers!

\section{Notes}

1. It is the return on a portfolio in excess of the risk free rate as proxied by the three month Treasury Bill rate.

2. The All Share Index is used as the market proxy in the CAPM (Van Rensburg \& Slaney, 1997: 11)

\section{References}

97 Unit Trusts Handbook. 1997. 3rd ed. Johannesburg: Profile Media.

Barr, G.D.I. 1989. Macroeconomic identification of the pricing factors on the Johannesburg Stock Exchange, South African Journal of Business Management, 21(1): 17-26.

Biger, N. \& Page, M.J. 1993. Unit trust performance: does the yardstick matter? Journal for Studies in Economics and Econometrics. 17(1): $1-15$

Biger, N. \& Page, M.J. 1994. Assessing portfolio performance: the case of flexible investment unit trusts, Journal for Studies in Economics and Econometrics, 18(3): 27-43.

Brown, S.J. \& Goetzmann, W.N. 1995. Performance persistance, The Journal of Finance, 50(2):, 679-698.

Carhart, M.M. 1997. On persistence in mutual fund performance, The Journal of Finance, 52(1): 57-82.

Davidson, S.R. 1993. The Capital Asset Pricing Model and Arbitrage Pricing Theory on the Johannesburg Stock Exchange. Unpublished MComm-thesis. Johannesburg: University of the Witwatersrand.

De Lange, L. 1996. Hoe om 'n cenheidtrust te kies, Finansies \& Teg niek, 21 June: 65.

De Lange, L. 1996. Waarom die trusts versigtig is, Finansies \& Tegniek, 18 October: 56

Elton, E.J., Gruber, M.J. \& Blake, C.R. 1996. The persistence of 
risk-adjusted mutual fund performance, Journal of Business, 69(2): 133-157.

Firer, C., Gray, P., Sandler, M. \& Ward, M. 1996. Market timing and unit trust: can you beat the market? South African Journal of Business Management, 27(3): 58-64

Garvin, T. 1995. A study of the relative performance of South African unit trust fund managers utilizing the portfolio change measure technique. Unpublished MComm-thesis. Cape Town: University of Cape Town.

Goetzmann, W.N. \& Ibbotson, R.G. 1994. Do winners repeat? Jour nal of Portfolio Management, 20: 9-18.

Grinblatt, M. \& Titman, S. 1992. The persistence of mutual fund performance, The Journal of Finance, 47(5): 1977-1984.

Hendricks, D., Patel, J. \& Zeckhauser, R. 1993. Hot hands in mutual funds: short-run persistence of relative performance, 1974-1988. The Journal of Finance, 48(1): 93-130.

Knight, E.T. \& Firer, C. 1989. The performance of South African unit trusts 1977-1986, The South African Journal of Economics, 57(1): 52-68.

Meyer, M.C. 1997. The persistence of unit trust performance for the period July 1985-June 1995. Paper delivered at the South African Finance Association Conference, Cape Town, 30 \& 31 January.

Oldfield, C.E. \& Page, M.J. 1997. Assessing portfolio performance: the case of South African unit trusts, Investment Analysts Journal, 44: $25-41$.

Page, M.J. 1985. Empirical testing of the arbitrage pricing theory using data from the Johannesburg Stock Exchange, South African Journal of Business Management, 17(1): 38-42.

Page, M.J. 1989. Model selection for measuring security price performance, South African Journal of Business Management, 20(2): 78-81

Page, M.J. 1993. The Arbitrage Pricing Theory: an assessment of the robustness of empirical techniques employed under conditions of thin trading and in the presence of non-normalities. Unpublished DBA-thesis. Cape Town: University of Cape Town Graduate School of Business.

Reese, B.K. 1993. The Arbitrage Pricing Theory in South Africa: an empirical study of the effect of pre-specified risk factors on share prices on the Johannesburg Stock Exchange. Unpublished MComm-thesis. Durban: University of Natal.

Ross, S.A. 1976. The arbitrage theory of capital asset pricing, Journal of Economic Theory, 13: 341-360.

Ross, S.A., Westerfield, R.W. \& Jordan, B.D. 1993. Fundamentals of corporate finance. 2nd ed. Richard D. Irwin, Inc

Slaney, K.B.E. 1995. An investigation into the share indices that proxy the macroeconomic forces underlying equity returns on the Johannesburg Stock Exchange. Unpublished MComm-thesis. Durban: University of Natal.

Smith, J. du P. \& Chapman, L.A. 1994. The timing and selection ability of South African unit trust portfolio managers. Paper presented at the South African Finance Association Conference, 3 \& 4 February.

Theron, S. 1996. Waar om te belê, Finansies \& Tegniek, 19 July, 9.

Van Rensburg, P. \& Slaney, K. 1997. Market segmentation on the Johannesburg Stock Exchange, Journal for Studies in Economics and Econometrics, 21(3): 1-23.

Van Rensburg, P. 1996. Macroeconomic identification of the priced APT factors on the Johannesburg Stock Exchange, South African Journal of Business Management, 27(4): 104-112.

Van Rensburg, P. 1997. Investment basics: the Arbitrage Pricing Theory, The Investment Analysts Journal, 44: 42-60.

Van Rensburg, P. 1998. Economic forces and the Johannesburg Stock Exchange. Unpublished PhD-thesis. Durban: University of Natal. 